\title{
Optimizing care transitions: the role of the community pharmacist [Corrigendum]
}

Melody KT, McCartney E, Sen S, Duenas G. Integr Pharm Res Pract. 2016;5:43-51.

The authors on this paper have advised us that they were contacted by one of the authors of reference number 40 notifying them that the author list for this reference was incorrect.

Page 51, reference number 40, "Liu Y, Kuehl P. Identification of medication discrepancies by community pharmacists during a comprehensive medication review in patients 1 week post hospitalization. J Am Pharm Assoc (2003). 2014;54(2):e76-e219." should be replaced by “Took R, Liu Y, Kuehl P. Identification of medication discrepancies by community pharmacists during a comprehensive medication review in patients 1 week post hospitalization. J Am Pharm Assoc (2003). 2014;54(2): e76-e219.”.

\section{Publish your work in this journal}

Integrated Pharmacy Research and Practice is an international, peerreviewed, open access, online journal, publishing original research, reports, reviews and commentaries on all areas of academic and professional pharmacy practice. This journal aims to represent the academic output of pharmacists and pharmacy practice with particular focus on integrated care. All papers are carefully peer reviewed to ensure the highest standards as well as ensuring that we are informing and stimulating pharmaceutical professionals. The manuscript management system is completely online and includes a very quick and fair peer-review system, which is all easy to use. Visit http://www.dovepress.com/testimonials.php to read real quotes from published authors. 